\title{
AGROCLIMATIC ZONING OF ARID SUBTROPICS OF THE AZERBAIJAN REPUBLIC AND ITS AGROECONOMIC EFFICIENCY
}

\author{
Hasanov R.Sh., Guliyev A.A. \\ Azerbaijan State University of Economics \\ 135, H. Aliyev str., Baku, AZ1072: rovshanhasanov56@gmail.com, \\ asiman.quliyev.1956@mail.ru
}

Keywords: subtropic, arid, agroclimate, climate, zoning

\begin{abstract}
Summary. The territory of Azerbaijan Republic is 8641.500 hectares, of which 4227.000 hectares of the total area are utilized in agriculture. The total sown area is 1454.000 hectares. The main reason is the underestimation of the natural resources of dry and arid subtropical areas. Determination of boundaries and internal territorial units of the subtropical climate is carried out in two ways. The particular subtropical zone's boundary is set at $-12^{\circ} \mathrm{C}$ and the transition zone's boundary is set at $-16^{\circ} \mathrm{C}$ by using the average annual absolute minimum air temperature. According to D.I.Shashko, an isoline with annual humidity index of $\mathrm{Md}=0.25$ is taken as the boundary of the arid zone. The upper boundary of arid zone corresponds to the boundary of the forest zone in the mountainous area and the lower boundary corresponds to the forest-steppe zone. The boundaries of arid areas within the subtropical zone are covered by $\mathrm{Md}=0.25$. It should also be noted that the $-12^{0} \mathrm{C}$ isothermal line is not justifying itself when defining subtropical boundaries. In the territory of Azerbaijan there are regions where at $-12^{\circ} \mathrm{C}$ the sum of active temperature is less than $3800^{\circ} \mathrm{C}$, sometimes $3400^{\circ} \mathrm{C}$. The agroclimatic zoning of arid subtropics of the Azerbaijan Republic was conducted, resulting in 1 country, 4 provinces, 3 subprovinces, 19 regions.
\end{abstract}

(C) 2019 Earth Science Division, Azerbaijan National Academy of Sciences. All rights reserved.

\section{Introduction}

Currently, the food problem is one of the country's most important problems. The recent economic development processes, the new economic policies carried out with the aim of agricultural development, on the first hand, require a comprehensive study of climate and land resources. Despite the large agroclimatic resources of the studied area, they are still not being utilized efficiently. The main reason for this is the underestimation of the natural resources of dry and arid subtropical areas and the lack of a unified approach to the determination of climatic criteria. The land fund of the Azerbaijan Republic is 8641.5 thousand hectares. 4227.000 hectares of the total area is used in agriculture. The total sown area in the country is 1454 thousand hectares.

We have investigated the agro-climatic resources of the region in order to use effectively the land resources of the Azerbaijan Republic. However, the climate resources of the area are still not completely utilized.

The valuable feature of the climate resources of the Azerbaijan Republic is the thermic potential of its subtropical areas. Subtropical climate forms $60 \%$ of the Azerbaijan Republic (Ayyubov, 1975). This great potential should be taken into account in the specialization of agriculture in the country, where the subtropical direction of the economy should be prioritized. Even though, dry and arid subtropic area is covering vast areas, they are used rarely. Calculations show that under the favorable irrigation conditions they are not inferior to the humid subtropical areas for their economic importance. Plain and foothill areas of the Republic have endless thermic potential (in most places with total annual active temperatures of $4000-4700^{\circ}$ ), including the large residual heat reserves. $40-60 \%$ of this reserve remains unused in agriculture every year. The first factor limiting the efficient utilization of arid subtropics' climate resources is the lack of humidity.

\section{Carried out research methods}

In this regard, it is appropriate to conduct agroclimatic zoning in arid subtropical areas of the Azerbaijan Republic. For the first time agroclimatic zoning in Russia was conducted by G.T.Selyaninov 
(1961) and in the territory of the Azerbaijan Republic it was conducted by A.D.Ayyubov (1968). The researches of Goltsberg (1956), P.I.Koloskov (1947), L.N.Babushkin (1960), Meladze, 1979, D.I.Shashko (1967), A.D.Ayyubov (1968) et al. provided the principles and methods of agroclimatic zoning. These principles and methods have defined not only agroclimatic zoning, but also how to utilize effectively climate resources in agriculture in specific areas. The main goal of the agroclimatic zoning conducted by researchers is the indicators of availability of the heat and humidity of agricultural (mainly heat and moisture) plants. In some cases winter conditions of perennial plants are also taken into account (Davitaya, 1964)

Using the method of G.T.Selyaninov (1961), L.N Babushkin (1960) provided the agroclimatic zoning of cotton fields in Central Asia, while A.D.Ayyubov (1968) provided agroclimatic zoning in the territory of the Azerbaijan Republic using the method of D.I.Shashko (1967). However, since this method belongs to the plain areas, it has been improved by A.D.Ayyubov and used in the agroclimatic zoning of areas with complex relief.

We used this method and took into account the wintering conditions (table 1) of arid subtropical plants (pomegranate, fig, olive, palm and almond), the annual irrigation rate (table 2) (Hasanov, 2018) and the heat supply conditions. Thus the climate boundaries, humidification zones of arid subtropics (particular and transitional zone) were determined and as a result agroclimate zoning was conducted (Fig. 1, 3).

Depending on the peculirities of the object, some additions have been made to the system, taking into account the physical and geographical conditions of the study area. Determination of the boundaries and internal territorial units of the subtropical climate is carried out in two ways:

1. The particular subtropical zone's boundary is set at $-12^{\circ} \mathrm{C}$ and the transition zone's boundary is set at $-16^{\circ} \mathrm{C}$ by using the average annual absolute minimum air temperature. It should be noted that this particular subtropical zone is a major part of the total subtropical territory of the Azerbaijan Republic.

2. According to D.I.Shashko (1967), an isoline with an annual humidity index of $\mathrm{Md}=0.25$ is taken as the boundary of the arid zone. The upper boundary of the arid zone corresponds to the boundary of the forest zone in the mountainous area and the lower boundary corresponds to the forest-steppe zone.

The main thermal indicators of growth and development of arid subtropical plants

Table 1

\begin{tabular}{|c|c|c|c|c|c|}
\hline \multirow{2}{*}{$\begin{array}{l}\text { Arid subtropic } \\
\text { plants }\end{array}$} & \multicolumn{2}{|c|}{$\begin{array}{l}\text { Average daily air } \\
\text { temperature }{ }^{\circ} \mathrm{C}\end{array}$} & \multirow{2}{*}{$\begin{array}{l}\text { Sum of daily } \\
\text { temperatures above } \\
10^{\circ} \mathrm{C} \text { during the } \\
\text { vegetation period }\end{array}$} & \multirow{2}{*}{$\begin{array}{l}\text { Duration of the } \\
\text { vegetation } \\
\text { period }\end{array}$} & \multirow{2}{*}{$\begin{array}{c}\text { Frosting feature } \\
\left({ }^{\circ} \mathrm{C}\right)\end{array}$} \\
\hline & $\begin{array}{l}\text { Leaf } \\
\text { production } \\
\text { period }\end{array}$ & $\begin{array}{l}\text { Leaf } \\
\text { sheddingpe } \\
\text { riod }\end{array}$ & & & \\
\hline Pomegranate & $9-12$ & $10-11$ & $>3800$ & $188-224$ & $\begin{array}{c}\text { Weak -12-(-15) } \\
\text { Strong -16-(17) } \\
\text { Fatal -18-(-20) }\end{array}$ \\
\hline Fig $^{* *}$ & $9-11$ & $10-11.5$ & $>3600$ & $207-218$ & $\begin{array}{c}\text { Weak -11-(-14) } \\
\text { Strong -15-(-17) } \\
\text { Fatal -17-(-20) }\end{array}$ \\
\hline Olive $e^{* * *}$ & $9-13$ & $\begin{array}{l}\text { Doesn’t } \\
\text { happen }\end{array}$ & $4000-4200$ & $216-220$ & $\begin{array}{c}\text { Weak -8-(-10) } \\
\text { Strong -11-(-15) } \\
\text { Fatal -16-(-18) }\end{array}$ \\
\hline $\begin{array}{l}\text { Persimmon } \\
\text { (Diospyros kaki) }\end{array}$ & $8-10$ & $8-12$ & $2800-4550$ & $195-238$ & $\begin{array}{c}\text { Weak -15-(-18) } \\
\text { Strong -19-(-20) } \\
\text { Fatal -21-(-22) }\end{array}$ \\
\hline Almond ${ }^{* * * * *}$ & $4-6$ & $8-12$ & $3500-4700$ & $220-230$ & $\begin{array}{c}\text { Weak -17-(-21) } \\
\text { Strong -22-(-25) } \\
\text { Fatal }-26(-28)\end{array}$ \\
\hline $\begin{array}{r}{ }^{*} \text { (Ragimo } \\
{ }^{* *} \text { (Ulkhan } \\
{ }^{* * * *} \text { (Abdulla } \\
{ }^{* * * * *} \text { (Gutiev } \\
* * * * * \\
\text { (Ayyubo }\end{array}$ & $\begin{array}{l}84) \\
986) \\
1976) \\
\text { iyash, 1977) } \\
\text { al., 1978) }\end{array}$ & & & & \\
\hline
\end{tabular}


Table 2 mal line is sometimes not justifying itself when de-

Climate irrigation norms of plants in arid subtropics by humidification zones

\begin{tabular}{|l|c|c|}
\hline $\begin{array}{c}\text { Humidification } \\
\text { zones }\end{array}$ & Md & $\begin{array}{c}\text { Lack of humidi- } \\
\text { ty, } \mathrm{mm}\end{array}$ \\
\hline Very dry & $<0.05$ & $>900$ \\
\hline Dry & $0.05-0.10$ & $900-700$ \\
\hline Semi-dry & $0.10-0.15$ & $700-500$ \\
\hline Arid & $0.15-0.25$ & $500-300$ \\
\hline
\end{tabular}

Temperature indicators of the boundaries of arid subtropics are defined by the average absolute minimum air temperature of -12 degrees, -16 degrees and the humidity index of 0.25 . That is, the boundaries of arid areas within the subtropical zone are covered by $M d=0.25$. In this case the temperature and humidity indicators coincide with each other. The boundaries of the arid subtropics were determined based on the reciprocal indicators of both lines. It should also be noted that the $-12{ }^{\circ} \mathrm{C}$ isother- fining subtropical boundaries. In the territory of the Azerbaijan Republic there are regions where at $-12^{\circ} \mathrm{C}$ the sum of active temperature is less than $3800^{\circ} \mathrm{C}$, sometimes $3400^{\circ} \mathrm{C}$. Such regions, for sure, do not provide normal growth of subtropical plants in some years.

As an example, the bottoms of South-East slopes which are 600-800 meters above sea level in the Greater Caucasus can be shown.

Therefore, climatic boundaries of arid subtropics in such areas are not determined by the average annual minimum air temperature, but the boundaries of these areas are determined with the sum of an active temperature of $3800^{\circ} \mathrm{C}$ (Fig. 2).

The agroclimatic zoning system of arid subtropics of the Azerbaijan Republic includes the following taxonomic territorial units: agroclimate country, province, subprovince and agroclimate district. The boundary of the country is based on the generally accepted principle of physical and geographical zoning ( Shikhlinsky, Gadzhiev, 1973).

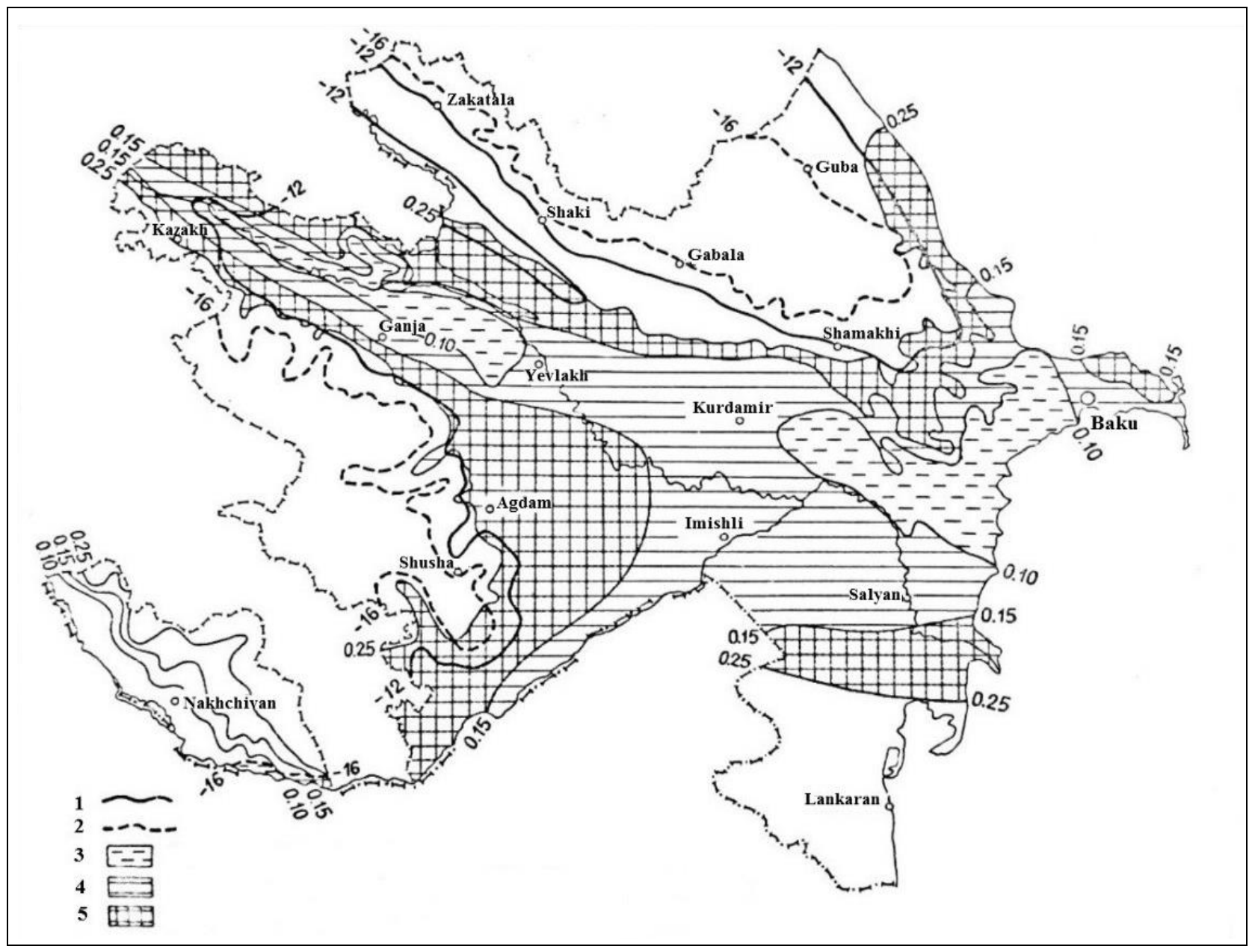

Fig. 1. Boundaries and humidification zones of the subtropical climate zone of the Azerbaijan Republic (boundaries: 1 - particular subtropics; 2 - transition zone; humidification zones: 3 - dry; 4 - semi-dry; 5 - arid) (Hasanov, 2018) 


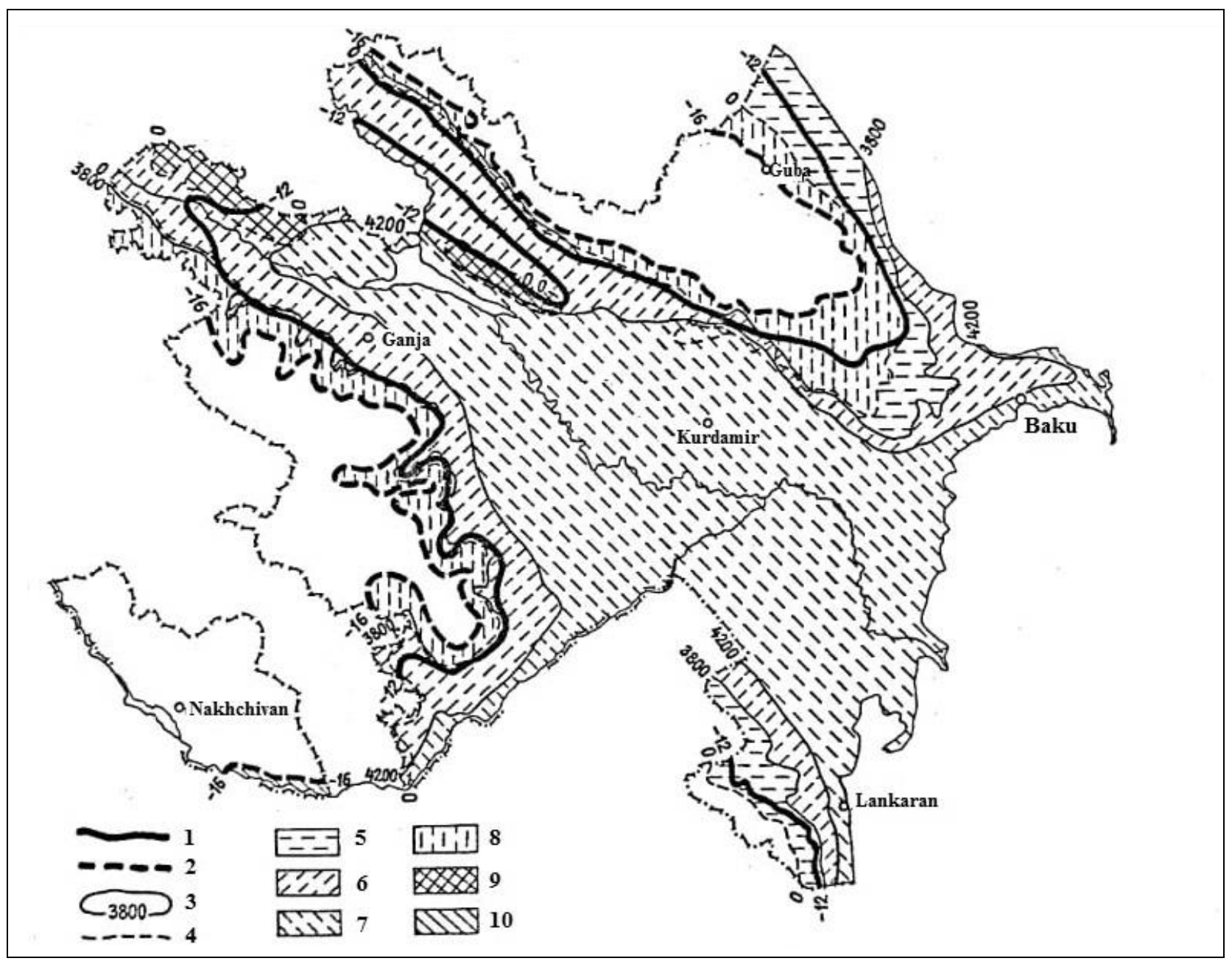

Fig. 2. Heat supply of arid subtropics of the Azerbaijan Republic. 1 - borders of the subtropics proper; 2 - transition zone boundaries; 3 - sums of average daily air temperatures above 10; 4 - January zero isotherm, moderate belt of the temperate zone; 5,8 stripes are more provided with heat: 5 - with very mild winters, 8 - with mild winter. Moderately warm girdle of a warm belt. Stripes: 6,9 - less provided heat, 7,10 - medium heat, 6,7 - better heat

The agroclimate province is surrounded by large mountain slopes of different directions but with suitable relief. Even though, in some places the borders of the province are limited by the state borders, beyond the borders of it the boundary of the province continues. The boundaries of the agroclimate subprovince are mainly determined by the direction of the large mountain slopes. The roads of the agroclimate regions are developed with the humidity coefficient Md. Based on these, the agroclimatic zoning of arid subtropics of the Azerbaijan Republic was conducted, resulting in 1 country, 4 provinces, 3 subprovinces, 19 regions (Fig. 3)

\section{Discussion of results}

The following are the characteristics of the agroclimate regions:

1. Province - The Great Caucasus;

1a. Subprovince - South slope:

1. Ceyranchol-Aghsu region which is characterised by foothills, arid, mild warm climate, low heat is situated at 150-800 meters height from sea level. The sum of average annual temperatures above $10^{\circ} \mathrm{C}$ is $4000-4500^{\circ} \mathrm{C}$, the duration of vegetation period is 260-280 days, and the residual sum of temperature above 10 degrees after the autumn wheat harvest (RTS) is $2200-2700^{\circ} \mathrm{C}$. The average annual absolute minimum temperature does not fall below than (-8)$(-10)^{0} \mathrm{C}$. During the perennial period the number of frostless days is $238-264$ days. In average perennial hot period $250-260 \mathrm{~mm}$ of precipitation falls. The amount of snowy days is 16-20 days. In average perennial period the number of days with dry wind is 10-40. Climatic conditions of the area allow cultivation of medium-grown cotton varieties, tobacco, dry subtropical, maple, fodder and vegetable crops.

2. Garayazi-Ceyranchol region which is characterised by foothills, semi-arid, mild warm climate, low heat is situated at 500-700 meters height from sea level. The sum of average annual temperatures above $10^{\circ} \mathrm{C}$ is $4000-4500^{\circ} \mathrm{C}$, the duration of vegetation period is $280-285$ days and the residual sum of 


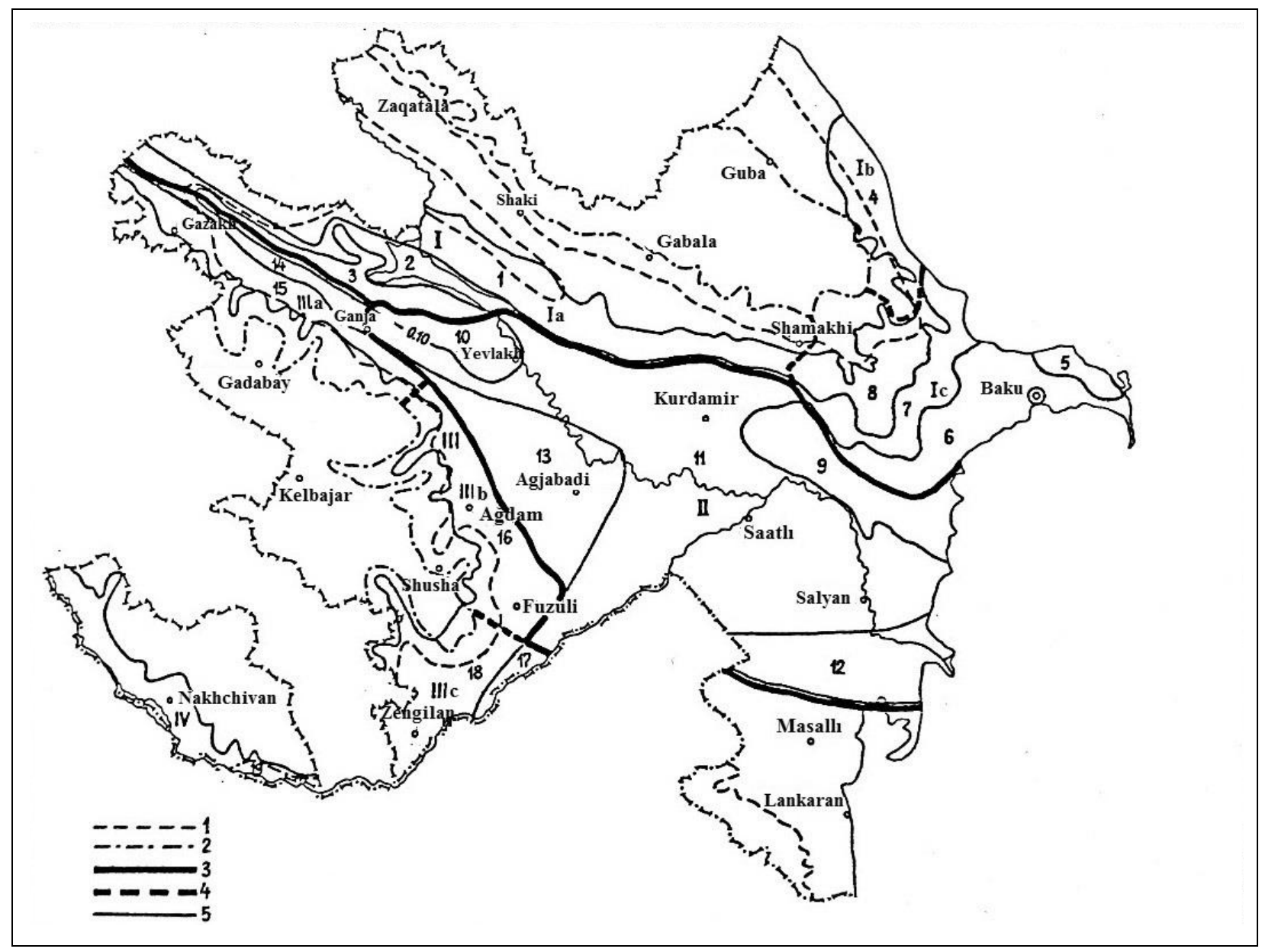

Fig. 3. Agroclimatic zoning of arid subtropics of the Azerbaijan Republic (boundaries: 1 -particular subtropics; 2 - transition zone; 3 - provinces (I-IV); 4 - subprovinces (Ia-IIIc); 5 - regions (1-19)

temperature above 10 degrees after the autumn wheat harvest (RTS) is $2200-2700^{\circ} \mathrm{C}$. The average annual absolute minimum temperature does not fall below than $(-10)-(-12)^{0} \mathrm{C}$. The number of frostless days is 240-264 days. About 220-240 mm precipitation falls in the hot period. The number of snowy days is $16-25$ days. The number of dry windy days is 5-10 days. The climatic conditions of the area allow the cultivation of grape varieties, figs, tobacco, dry subtropical plants, fodder, vegetables and perennial plants. Climatic conditions of the district allow to grow products twice a year and to grow alfalfa 2-3 times a year.

3. Bozdagh-Mingachevir region which is characterised by lowland foothills, dry, mild warm climate, low heat is situated at 100-550 meters height from sea level. The sum of average annual temperatures above $10^{\circ} \mathrm{C}$ is $4400-4600^{\circ} \mathrm{C}$, the duration of vegetation period is $280-300$ days and the residual sum of temperature above 10 degrees after the autumn wheat harvest (RTS) is $2600-2800^{\circ} \mathrm{C}$. The average annual absolute minimum temperature does not fall below than $(-8)-(-10)^{0} \mathrm{C}$. The number of frostless days is 235-245 days. About 150-180 mm precipitation falls in the hot period. The number of snowy days is 8-10 days. The number of dry windy days is 40-45 days. Late growing varieties of cotton, grapes, dry subtropical plants (figs, pomegranates, ziziphus, almonds, quince, pistachios, etc.), lateripening corn, melons and gourds can be grown in the area of the district with the high level of heat reserves. In the district it is possible to grow oneyear plants 2-3 times and 3-4 times the alfalfa a year.

1b. Subprovince - North-East slope

4. Khacmaz-Siyazan region which is characterised by lowland hill plains, arid, mild warm climate, low heat is situated at (-20)-500 meters height from sea level. The sum of average annual temperatures above $10^{\circ} \mathrm{C}$ is $3800-4000^{\circ} \mathrm{C}$, the duration of vegetation period is $230-255$ days and the residual sum of temperature above 10 degrees after the autumn wheat harvest (RTS) is $2000-2200^{\circ} \mathrm{C}$. The average annual absolute minimum temperature does not fall below than $(-10)-(-12)^{0} \mathrm{C}$. The number of frostless days is $235-245$ days. About $160-170 \mathrm{~mm}$ precipitation falls in the hot period. The number of snowy days is $14-16$ days. The number of dry windy days is 10-20 days. Grain, melons and gourds, fruit 
and grapes are grown in this district. After the autumn harvest it is possible to obtain a second crop from some feed crops (corn, rapeseed) due to the residual temperatures in the area.

\section{1c. Subprovince - Absheron-Gobustan}

5. Buzovna-Pirsaat region which is characterised by lowland plains, arid, mild warm climate, low heat is situated at (-20)-400 meters height from sea level. The sum of average annual temperatures above $10^{\circ} \mathrm{C}$ is $4200-4400^{\circ} \mathrm{C}$, the duration of vegetation period is 280-290 days and the residual sum of temperature above 10 degrees after the autumn wheat harvest (RTS) is $2400-2600^{\circ} \mathrm{C}$. The average annual absolute minimum temperature does not fall below than (-6)$(-8)^{0} \mathrm{C}$. The number of frostless days is $252-270$ days. About $70-110 \mathrm{~mm}$ precipitation falls in the hot period. The number of snowy days is 4-10 days. The number of dry windy days is 10-20 days. These areas which have a high level of heat reserves can produce high quality heat-loving plants, arid subtropical plants, grapes as well as industrially important plants such as saffron, through artificial irrigation.

6. Absheron region which is characterised by hilly plain, dry, mild warm climate, medium heat is situated at (-20)-(400) meters height from sea level. The sum of average annual temperatures above $10^{\circ} \mathrm{C}$ is $4200-4400^{\circ} \mathrm{C}$, the duration of vegetation period is 290-300 days, and the residual sum of temperature above 10 degrees after the autumn wheat harvest (RTS) is $2400-2600^{\circ} \mathrm{C}$. The average annual absolute minimum temperature does not fall below than (-6)$(-8)^{0} \mathrm{C}$. The number of frostless days is $252-270$ days. Only about $50-100 \mathrm{~mm}$ precipitation falls in the hot period. The number of snowy days is 3-5 days. The number of dry windy days is 10-20 days. This climate condition allows to produce industrially important saffron that have no analogues in the CIS. The hilly plain area is used as winter deposits due to the absence of irrigation canals in the west and southwest of the area. Despite the favorable climate and land resources this area is not used effectively.

7. South Gobustan region which is is characterised by a range of plain with hills, semi-arid, mild-warm climate and warmth is situated at 28-350 $\mathrm{m}$ height from sea level. The weather temperature sum above $10^{\circ} \mathrm{C}$ is only $4400-4500^{\circ} \mathrm{C}$, the length of vegetation period is 290-300 days, and RTC is 2600$2700^{\circ} \mathrm{C}$, more than $10^{\circ} \mathrm{C}$ after the autumn wheat harvest. The average annual absolute minimum temperature does not fall below $(-6)-(-8)^{0} \mathrm{C}$. The number of frost-free days is $240-270$. Only about $50-120 \mathrm{~mm}$ of precipitation falls in the hot period. The number of snowy days is 4-6 days. The number of dry windy days forms 20-30 days. High quality products can be obtained from arid subtropical plants (olives, pomegranates, figs, almonds, unabi etc.) in the areas with a large heat supply and favorable wintering conditions. The western and southwestern hilly areas of the district are not used as winter pasture due to lack of irrigation canals.

8. North Gobustan region which is characterised by foothills, arid, mild warm climate and warmth covers is situated at 500-800 $\mathrm{m}$ height from the sea level. The weather temperature sum above $10^{\circ} \mathrm{C}$ is $3800-$ $4200^{\circ} \mathrm{C}$, the length of vegetation period is $234-250$ days, and RTC is $2000-2400^{\circ} \mathrm{C}$ above $10^{\circ} \mathrm{C}$ after the autumn wheat harvest. The average annual minimum air temperature does not fall below $(-8)-(-10)^{0} \mathrm{C}$. The number of frostless days is 200-400. Only $100-200 \mathrm{~mm}$ of precipitation falls in the hot period. The amount of snowy days varies from 4 to 40 days in different areas. The number of days with dry wind is 20-30 days. Agro-climatic resources of the region create favorable conditions for the cultivation of grapes, cereals, melons and gourds, fodder crops and fruit crops. After the autumn harvest it is possible to obtain a second crop from some feed plants (corn, rape) due to the residual temperatures in the area.

\section{Province -Kur-Araz lowland}

9. Southern Shirvan-Alat region which is characterised by low plain, arid and mild climate, warmth is situated at $28-300 \mathrm{~m}$ height from the sea level. The weather temperature sum above $10^{\circ} \mathrm{C}$ is only $4500-4600^{\circ} \mathrm{C}$, the vegetation period is $290-296$ days, and RTC is $2700-2800^{\circ} \mathrm{C}$, more than $10^{\circ} \mathrm{C}$ after the autumn wheat harvest. The average annual absolute minimum temperature does not fall below $(-6)-(-8)^{0} \mathrm{C}$. The number of frostless days is $230-266$. Only $80-90 \mathrm{~mm}$ of precipitation falls in the hot period. The number of snowy days is 4-6 days. The number of dry windy days varies between 10 and 30 days. Large heat reserves of the region allow cultivation of medium maturity cotton species, lategrowing corn, melons and gourds, arid subtropical plants, grapes etc. can be grown. Due to the residual temperatures it is possible to harvest twice a year and mow clover 3-4 times. Although there are up to 30 days of dry winds in these areas, it does not affect the development and productivity of the plants. This is because plants are provided with irrigation norms.

10. Ganja-Yevlakh region which is characterised by low plain, dry and mild climate, warmth is situated at the 10-250 m height from the sea level. The weather temperature sum above $10^{\circ} \mathrm{C}$ is 4000 $4600^{\circ} \mathrm{C}$, the vegetation period is $270-286$ days, and RTC is $2200-2800^{\circ} \mathrm{C}$ above $10^{\circ} \mathrm{C}$. The average annual minimum air temperature does not fall below (-8)$(-10){ }^{0} \mathrm{C}$. The number of frostless days is $235-245$. The number of snowy days is 5-8 days. The number of dry windy days varies between 30-45 days. The large heat reserves of the area and favorable winter conditions for the plants allow cultivation of cereals, 
tobacco, cotton, arid subtropical plants. It is possible to grow clover 2-3 times a year and harvest 3-4 times in these areas. As the plants are supplied with irrigation norms, dry winds do not adversely affect the development and productivity of plants.

11. Shirvan-Mughan central region which is characterised by plain hills, semi-dry and mild climate, warmth is situated at altitudes below $200 \mathrm{~m}$ sea level. The weather temperature sum above $10^{\circ} \mathrm{C}$ is only $4400-4600^{\circ} \mathrm{C}$, the vegetation period is 280 285 days, and $\mathrm{RTC}$ above $10^{\circ} \mathrm{C}$ is $2600-2800^{\circ} \mathrm{C}$. The average annual absolute minimum temperature does not fall below $(-8)-(-12)^{0} \mathrm{C}$. The number of frostless days is $244-248$. $180-200 \mathrm{~mm}$ of precipitation falls in the hot period. The number of snowy days is 1012 days. The number of days with dry wind varies between 30-45 days. Agro-climatic resources of the region allow the cultivation of very hot arid subtropical plants. Residual temperatures allow to crop twice a year and to harvest clover 3-4 times. Due to the good climate and irrigation conditions, dry winds do not prevent the development of plants.

12. Bilasuvar-Neftchala region which is characterised by lowland, arid, mild warm climate with average heat is at (-28)-70 $\mathrm{m}$ height from the sea level. The weather temperature sum above $10^{\circ} \mathrm{C}$ is $4400-4500^{\circ} \mathrm{C}$, the length of the vegetation period is 280-285 days, and RTC is $2600-2700^{\circ} \mathrm{C}$. The average annual minimum air temperature does not fall below $(-8)-(-10)^{0} \mathrm{C}$. The number of frostless days is $240-265$. In the hot period $120-130 \mathrm{~mm}$ of precipitation falls. The number of snowy days is $14-16$ days. The number of dry windy days varies from 20 to 40 days. Agro-climatic conditions of the region allow cultivation of cotton, late growing corn, melons and vegetables, arid subtropical plants and different grape varieties. Due to the residual temperatures, it is possible to crop 2-3 times a year and harvest clover 3-4 times.

13. Barda-Aghjabadi region which is characterised by lowland, plain, arid and mild warm climate with average heat is situated at (-15)-200 m height from the sea level. The weather temperature sum above $10^{\circ} \mathrm{C}$ is $4400-4500^{\circ} \mathrm{C}$, the length of vegetation period is 280-285 days, and RTC is 2600$2700^{\circ} \mathrm{C}$. The average annual minimum air temperature does not fall below $(-8)-(-10)^{0} \mathrm{C}$. The number of frostless days is 245-255. The number of snowy days is 9-12 days. The number of dry windy days varies between 20 and 30 days. The region with high agro-climatic conditions allows growing some moist-arid subtropical plants, such as lemons and grapes, besides fruit crops. Due to the residual temperatures, it is possible to crop 2-3 times a year and harvest clover 3-4 times. Climate conditions and irrigation norms prevent the negative effects of dry winds on plant development in the area.

\section{Province - Small Caucasus}

3a. Sub- province - Northern slope

14. Ganja-Agstafa region which is characterised by plain, semi-dry, mild warm climate with low heat is situated at $200-400 \mathrm{~m}$ height from the sea level. The weather temperature sum above $10^{\circ} \mathrm{C}$ is $4000-4200^{\circ} \mathrm{C}$, the length of vegetation period is 260 270 days, and RTC is above $2200-2400^{\circ} \mathrm{C}$. The average absolute minimum air temperature is below ($10)-(-12)^{0} \mathrm{C}$. The number of frostless days is 230 250. In the hot period $280-290 \mathrm{~mm}$ of precipitation falls. The number of snowy days is 10-15 days. The number of dry windy days varies between 10 and 20 days. Favorable climatic conditions allow for the cultivation of cereals, tobacco, subtropical and melons. Due to the residual temperatures, it is possible to crop 2-3 times a year from this area, and harvest clover 2-3 times.

15. Shamkir-Gazakh region which is characterised by low plain, arid and mild warm climate with low-temperature is situated at $200-500 \mathrm{~m}$ height from sea level. The weather temperature sum above $10^{\circ} \mathrm{C}$ is $3800-4000^{\circ} \mathrm{C}$, the length of vegetation period is $260-$ 270 days, and RTC is above $2000-2200^{\circ} \mathrm{C}$. The average absolute minimum air temperature is below (-10)$(-12)^{0} \mathrm{C}$. The number of frostless days is $220-250.230-$ $270 \mathrm{~mm}$ of precipitation falls in the hot period. The number of snowy days is 4-11 days. The number of dry windy days varies between 10 and 20 days. These climatic conditions are best suited to grow cereals, melons and grapes in the area. It is possible to grow some forage crops (corn, rape, etc.) due to the residual temperatures in the area.

3b Sub-province - Eastern slope

16. Aghdam-Fizuli region which is characterised by plain with hill, arid and mild warm climate with low heat is situated at 200-1000 m height from the sea- level. The weather temperature sum above $10^{\circ} \mathrm{C}$ is $3800-4000^{\circ} \mathrm{C}$, the length of vegetation period is 260 270 days, and QTC is above $2000-2200^{\circ} \mathrm{C}$. The average absolute minimum air temperature is below -10-($12)^{0} \mathrm{C}$. The number of frostless days is $237-244$. In the warmer period rainfall is $290-300 \mathrm{~mm}$. The number of snowy days is $13-25$ days. The number of dry windy days varies between 20 and 30 days. Favorable agroclimatic conditions allow the cultivation of humid oriented fruits, dry subtropical plants, grapes, cotton and cereals. Due to the residual temperatures, it is possible to grow plants in this area for a short growing season. Due to high irrigation norms, repeated dry winds do not affect the productivity and development of plants.

\section{3c Sub-province - South slope}

17. Lower Hakkari region which is characterised by plain, semi-arid and mild warm climate with low heat is situated at $200-500 \mathrm{~m}$ height from the sea level. The weather temperature sum above $10^{\circ} \mathrm{C}$ is 
$4200-4400^{\circ} \mathrm{C}$, the length of vegetation period is 260 285 days, and RTC is above $2400-2600^{\circ} \mathrm{C}$. The average absolute minimum air temperature is below ($10)-(-12)^{0} \mathrm{C}$. The number of frostless days is 230 250. In the hot period $100-120 \mathrm{~mm}$ of precipitation falls. The number of snowy days is $18-20$ days. The number of dry windy days varies between 10 and 30 days. Large heat reserves of the region allow cultivation of arid subtropical fruit crops, nuts, melons, cereals, tobacco and various varieties of grapes. Due to the residual temperatures, it is possible to harvest 23 times a year fodder crops and 3-4 times clover.

18. Lachin-Gubadli region which is characterised by low and middle mountainous areas, arid and mild climate with low heat is situated at 500-1200 m height from the sea- level. The weather temperature sum above $10^{\circ} \mathrm{C}$ is $3800-4200^{\circ} \mathrm{C}$, the length of vegetation period is 230-279 days, and RTC is above $2000-2400^{\circ} \mathrm{C}$. The average annual minimum air temperature does not fall below $(-12)-(14)^{0} \mathrm{C}$. The number of frostless days is 210-240. In the hot period the amount of precipitation is $350-400 \mathrm{~mm}$. The amount of snowy days is 18-52 depending on the area. The number of dry windy days varies between 10 and 20 days. Agro-climatic conditions of the area allow cultivation of cereals, melons and gourds, fodder plants, fruit crops, as well as some types of arid subtropical plants and nuts. Due to the residual temperatures, it is possible to grow corn and rape belonging to a short vegetation period from this area.

\section{Region - Nakhchivan AR}

19. Julfa-Ordubad region which is characterised by low mountainous areas and foothill plains, arid and mild warm climate with low heat is situated at 700-1000 m height from the sea level. The weather temperature sum above $10^{\circ} \mathrm{C}$ is $4000-4800^{\circ} \mathrm{C}$, the length of vegetation period is $230-279$ days, and RTC is above $2200-2400^{\circ} \mathrm{C}$. The average annual minimum air temperature does not fall below (-14)-

\section{REFERENCES}

Abdullaev V.G. Agroclimatic resources of the Azerbaijan SSR for the reason of cultivation of olive crops. Abstract of $\mathrm{PhD}$ dissertation (geography sciences). Baku, 1976, 22 p. (in Russian).

Ayyubov A.D. Agroclimatic zoning of the Azerbaijan SSR. AS of the Azerb. SSR. Baku, 1968, 187 p. (in Russian).

Ayyubov A.D. Climate control of Azerbaijan SSR. Elm. Baku, 1975, 148 p. (in Russian).

Ayyubov A.D., Ragimov H.Sh., Ulkhanov N.D. Study of the climatic conditions of fruit subtropical crops and their agricultural assessment (pomegranate, fig, persimmon, almond). Fund of the Institute of Geography of the Academy of Sciences of Azerbaijan Republic, Baku, 1978, 386 p.

Babushkin L.N. Agroclimatic zoning of the cotton zone of Central Asia. Gidrometeoizdat. Leningrad, 1960, 134 p. (in Russian).
$(-16)^{0} \mathrm{C}$. The number of frostless days is $220-230$. In the hot period the amount of precipitation is $100-150$ $\mathrm{mm}$. The number of snowy days is $18-30$ days. The number of dry windy days is 30-50 days. Agroclimatic conditions of the region allow to plant walnut, unabi, peach, apricot, melon, high-quality grapes, tobacco crops, etc. protecting from cold. Due to residual temperatures, it is possible to harvest clover 2-3 times in a year. The strong and frequent blowing dry winds in some areas have a negative impact on the growth and productivity of plants.

\section{Conclusion}

- The boundary of the individual subtropical zone which forms the main part of the total subtropical territory of the Azerbaijan Republic is defined as $-12^{\circ} \mathrm{C}$ and the border of the transition zone is $-16^{\circ} \mathrm{C}$.

According to D.I.Shashko the average humidity indicators of $\mathrm{Md}=0.25$ is taken as the boundary of the arid zone. Temperature indicators of the arid subtropics are defined by the average absolute minimum air temperature of $-12^{\circ} \mathrm{C}$ and $-16^{\circ} \mathrm{C}$, and the humidity coefficient is 0.25 . That is, the boundaries of arid areas within the subtropical zone are covered by $\mathrm{Md}=0.25$. In this case the temperature and humidity indicators coincide. According to the interaction of both lines the boundaries of the arid subtropics were determined.

- The agroclimatic zoning system of arid subtropics of the Azerbaijan Republic includes the following taxonomic territorial units: agroclimate country, province, semi-province and agro-climate region. The boundaries of the agro-climate regions are characterized by humidity coefficient Md. Based on these the agroclimatic zoning of arid subtropics of the Azerbaijan Republic was conducted, as a result 1 country, 4 provinces, 3 sub-provinces, 19 districts have been defined.

\section{ЛИТЕРАТУРА}

Həsənov R.Ş. Đtraf mühitin iqtisadiyyatı. Dorslik. İqtisad Universiteti Nəşriyyatı. Bak1, 2018, 556 s.

Абдуллаев В.Г. Агроклиматические ресурсы Азербайджанской ССР для целей возделывания культур маслины. Автореф. дисс. на соиск. учен. степ. канд. географ. наук. Баку, 1976, $22 \mathrm{c.}$

Бабушкин Л.Н. Агроклиматическое районирование хлопковой зоны Средней Азии. Гидрометеоиздат. Ленинград, 1960, $134 \mathrm{c}$.

Гольцберг И.А. Климатические описания с учетом требований сельскохозяйственного производства. В сб.: А.И.Воейков и современные проблемы климатологии. Гидрометеоиздат. Ленинград, 1956, 241 с.

Гутиев Г.Т., Мосияш А.С. Климат и морозостойкость субтропических растений. Гидрометеоиздат. Ленинград, $1977,278 \mathrm{c}$. 


\title{
Geography
}

Davitaya F.F. The forecast of heat supply and some problems of the seasonal development of nature. Gidrometeoizdat. Moscow, 1964, 132 p. (in Russian).

Goltsberg I.A. Climatic descriptions taking into account the requirements of agricultural production. In: A.I.Voeikov and modern problems of climatology. Gidrometeoizdat. Leningrad, 1956, 241 p. (in Russian).

Gutiev G.T., Mosiyash A.S. Climate and frost resistance of subtropical plants. Hydrometeoizdat. Leningrad, 1977, 278 p. (in Russian).

Hasanov R.Sh. Environmental economics. Economic University Publishing. Baku, 2018, 556 p. (in Azerbaijani).

Koloskov P.I. Agroclimatic zoning of Kazakhstan. Publishing of AS of USSR. Moscow, 1947, p.147 (in Russian).

Meladze G.G. Agroclimatic basis for the cultivation of subtropical industrial and essential oil crops. Hydrometeoizdat. Leningrad, 1979, 136 p. (in Russian).

Ragimov H.Sh. Agroclimatic conditions and resources of pomegranate cultivation in the Azerbaijan SSR. Abstract of $\mathrm{PhD}$ diss. (geography). Baku, 1984, 24 p. (in Russian).

Selyaninov G.T. Prospects for the subtropical economy of the USSR in connection with natural conditions. Hydrometeoizdat. Leningrad, 1961,195 p. (in Russian).

Shashko D.I. Agroclimatic zoning of USSR. Kolos. Moscow, 1967, 336 p. (in Russian).

Shikhlinsky E.M., Gadzhiev G.A. The study of the patterns of climate variation and change according to individual meteorological elements and their complex in the Eastern Caucasus and Caspian Sea conditions with the identification of their connection with solar-terrestrial macroprocesses. Fund of the Institute of Geography of the Academy of Sciences of Azerbaijan Republic, Baku, 1973, 247 p. (in Russian).

Ulkhanov N.D. Agroclimatic conditions and cultivation resources of fig culture in Azerbaijan SSR. Abstract of $\mathrm{PhD}$ diss. (geography sciencies). Baku. 1986, 23 p. (in Russian).
Давитая Ф.Ф. Прогноз обеспеченности теплом и некоторые проблемы сезонного развития природы. Гидрометеоиздат. Москва, 1964, 132 с.

Колосков П.И. Агроклиматическое районирование Казахстана. Изд. АН СССР. Москва, 1947, 147 с.

Меладзе Г.Г. Агроклиматические основы возделывания субтропических технических и эфиромасличных культур. Гидрометеоиздат. Ленинград, 1979, 136 с.

Рагимов Х.Ш. Агроклиматические условия и ресурсы возделывания граната в Азербайджанской ССР. Автореф. дисс. на соиск. учен. степ. канд. географ.наук. Баку, 1984, 24 с.

Селянинов Г.Т. Перспективы субтропического хозяйства СССР в связи с природными условиями. Гидрометеоиздат. Ленинград, 1961, 195 с.

Улханов Н.Д. Агроклиматические условия и ресурсы возделывания культуры инжира в Азербайджанской ССР. Автореф. дисс. на соиск. учен. степ. канд. географ. наук. Баку, 1986, 23 с.

Шашко Д.И. Агроклиматическое районирование СССР. Колос. Москва, 1967, 336 с.

Шихлинский Э.М., Гаджиев Г.А. Изучение закономерностей колебания и изменения климата по отдельным метеорологическим элементам и по их комплексу в условиях Восточного Кавказа и Каспийского моря, с выявлением их связи с солнечно-земными макропроцессами. Фонды Инта географии АН Азерб. Республики, Баку, 1973, 247 с.

Эйюбов А.Д. Агроклиматическое районирование Азербайджанской ССР. Изд. АН Аз.ССР. Баку, 1968, 187 с.

Эйюбов А.Д. Бонитировка климата Азербайджанской ССР. Элм. Баку, 1975, 148 с.

Эйюбов А.Д., Рагимов Х.Ш., Улханов Н.Д. Изучение климатических условий плодовых субтропических культур и их сельскохозяйственная оценка (гранат, инжир, хурма, миндаль). Фонды Ин-та географии АН Азерб. Республики, Баку, 1978, 386 с.

\section{АГРОКЛИМАТИЧЕСКОЕ РАЙОНИРОВАНИЕ АРИДНЫХ СУБТРОПИКОВ АЗЕРБАЙДЖАНСКОЙ РЕСПУБ- ЛИКИ И ЕГО АГРОЭКОНОМИЧЕСКАЯ ЭФФЕКТИВНОСТЬ}

\author{
Гасанов Р.Ш., Гулиев А. А. \\ Азербайджанский Государственный Экономический Университет \\ AZ1072, Баку, ул акад.Г.Алиева, 135: rovshanhasanov56@gmail.com, \\ asiman.quliyev.1956@mail.ru
}

Резюме. Общая площадь нашей республики составляет 8641.5 тыс. га, из них 4227 тыс. га используются в сельском хозяйстве, а 4879.5 га находятся в засушливой (аридной) субтропической зоне. Агроклиматические ресурсы исследуемой территории огромны, однако до сих пор они используются недостаточно и крайне нерационально. Главной причиной этого является неудовлетворительная оценка природных возможностей и отсутствие единого подхода к определению климатических критериев субтропичности и аридности территорий.

Граница рассматриваемой территории и рубежи внутренних подразделений определены путем использования в основном двух критериев:

1) Средние из абсолютных годовых минимумов температуры воздуха $\left(-12^{\circ} \mathrm{C}\right.$ для выделения собственно субтропической зоны и $-16^{\circ} \mathrm{C}$ - переходной субтропической зоны), здесь уместно отметить, что собственно субтропическая зона в пределах Азербайджана является частью общей субтропической зоны в целом.

2) Показатель годового увлажнения (Md) доходит до 0,25. Согласно Д.И.Шашко, изолиния с $\mathrm{Md}=0.25$, используется в качестве границы засушливой зоны, выше которой в горах распространяются леса, а ниже - лесостепь.

Субтропики, где преобладают величины коэффициента увлажнения ниже 0.25 и средние из абсолютных минимумов температуры воздуха $-12^{\circ}$ и $-16^{\circ}$ располагаются внутри ареала аридной зоны, граница аридных субтропиков определяется по термическому признаку. В случае же расположения аридной территории внутри субтропической зоны, эта граница проводится по $\mathrm{Md}=0.25$. Однако следует отметить, что линия $-12^{\circ}$ не везде принята за границу субтропиков. В Азербайджане имеются районы, где в пределах температур выше $-12^{\circ}$ суммы активных температур составляют менее $3800^{\circ}$, даже $3400^{\circ}$. Эти районы в отдельные годы, естественно, не могут обеспечить нормальный рост субтропических культур. Исходя из этого, было проведено агроклиматическое районирование засушливых субтропиков Азербайджанской Республики, в результате были выделены: 1 страна, 4 области, 3 подобласти, 19 районов.

Ключевые слова: субтропический, аридность, агроклиматический, климатический, районирование 


\title{
AZORBAYCAN RESPUBLIKKASININ ARID SUBTROPIKLZRINIIN AQROIQLLIM RAYONLAŞMASI Və ONUN AQROIQTISADİ SəMӘRəLILIYYI
}

\author{
Həsənov R.Ş., Quliyev A.A. \\ Azarbaycan Dövlat Iqtisad Universiteti \\ AZ1072, Bakı şəh.., H.Oliyev küç., 135: rovshanhasanov56@gmail.com, \\ asiman.quliyev.1956@mail.ru
}

Azərbaycan Respublikasının torpaq fondu 8641.5 min ha-dır. Bu fondun 4227 min ha-rı kənd təsərrüfatında istifadə edilir. Ölkədə əkin sahələri 1454 min ha sahə tutur. Tədqiq olunan ərazinin aqroiqlim ehtiyatları böyük olmasına baxmayaraq bu günə qədər onlardan səmərəli istifadə edilmir. Bunun əsas səbəbi quru və quraq subtropik ərazilərin təbii imkanlarının düzgün qiymətləndirilməməsi və iqlim meyarını müəyyənləşdirməyə vahid yanaşmanın olmamasıdır. Subtropik iqlim qurşağının sərhədləri və daxili ərazi vahidlərinin müəyyən edilməsi əsasən iki üsulla aparılmışıdır:

Havanın ortaillik mütləq minimum temperaturu vasitəsilə məxsusi subtropik zonanın sərhədi $-12^{0} \mathrm{C}$, keçid zonanın sərhədi isə $16^{\circ} \mathrm{C}$ müəyyən edilmişdir. Qeyd etmək lazımdır ki, məxsusi subtropik zona Azərbaycan Respublikasının ümumi subtropik ərazisinin əsas hissəsini təşkil edir.

D.İ.Şaşkoya görə illik rütubətlənmə göstəricisi $\mathrm{Md}=0.25$ olan izoxətt quraq zonanın sərhədi kimi götürülür. Quraq zonanın yuxarı sərhədi dağlıq ərazidə meşə zonasının, aşağı sərhəddi isə meşə-çöl zonasının sərhədinə uyğun gəlir. Arid subtropiklərin sərhədlərinin temperatur göstəriciləri, havanın ortaillik mütləq minimum temperaturu $-12^{\circ} \mathrm{C}$ və $-16^{0} \mathrm{C}$, rütubətlənmə əmsalı isə 0.25 həddi ilə müəyyən edilir. Subtropik zona daxilindəki arid ərazilərin sərhədləri $\mathrm{Md}=0.25$ ilə əhatə olunur. Onu da qeyd etmək lazımdır ki, subtropiklərin sərhədlərinin təyini zaman $1-12^{\circ} \mathrm{C}$-lik izotermiki xətt bəzən özünü doğrultmur. Azərbaycan Respublikası ərazisində elə rayonlar var ki, $-12{ }^{\circ} \mathrm{C}$ temperaturda fəal temperatur cəmi $3800{ }^{\circ} \mathrm{C}$-dən aşağı, bəzən $3400^{\circ} \mathrm{C}$ olur. Belə rayonlar, təbii ki, bəzi illərdə subtropik bitkilərin normal inkişafını təmin etmir.

Bunlara əsaslanaraq, Azərbaycan Respublikasının arid subtropiklərinin aqroiqlim rayonlaşdırılması aparılmış, nəticədə 1 ölkə, 4 vilayət, 3 yarımvilayət, 19 rayon müəyyən edilmişdir.

Açar sözlor: subtropik, quraq, aqroiqlim, iqlim, rayonlaşdırma 